\title{
Financial Crises and Impacts of Recent Financial Crises on Sri Lanka ${ }^{1 /}$
}

\author{
W. M. Hemachandra
}

Assistant Governor

Central Bank of Sri Lanka

\begin{abstract}
The subject of financial crises has been widely addressed in the current literature. A series of researches has been conducted, and substantial volume of literature is available worldwide on various aspects of financial crises. This paper describes, among other things, about the Sri Lankan situation in regard to financial crises, particularly the recent crisis started in the United States of America (US). The paper briefly explains different views of financial crises that have evolved around the world. It identifies some possible causes of financial crises based on the experiences faced by different countries while presenting case studies explaining financial/economic crises in Argentina, Chile, Mexico, SouthEast Asia and the latest in the US. As regards the US crisis, a reference has been made to effects of the crisis and the responses made by the authorities to resolve it. The paper also highlights some lessons that could be learnt from the US financial crisis. In relation to Sri Lanka, this paper presents a description under four sub-topics, i.e., a brief account of the previous financial crises in Sri Lanka, effects of the recent US crisis on the Sri Lankan economy, the measures that contributed to minimise the impact of the US crisis on the Sri Lankan economy and how the Sri Lankan economy revived.
\end{abstract}

1/ The author is thankful to Dr. N. E. H. Sandaratne, who was a former central banker, for making editorial corrections. Mrs. C. S. Jayaweera and Mrs. C. R. Kurera, Personal Assistants of the Central Bank helped in word processing. 


\section{Introduction}

A situation in which financial institutions or assets suddenly lose a large part of their value is considered as a financial crisis. Financial crises are not new to the world. According to available literature, financial crises in the world date back to 1819 when there was a major financial crisis in the United States of America.

There are two schools of thought on the causes of financial crises and bank failures (Thomas, Balino, 1987). The first focuses on macro economic causes of financial crises which are generally beyond the control of individual financial institutions. One sub group suggests that financial crises are caused by a loss of public trust in the ability of banks to honour their commitments which is aggravated by errors in monetary policy. The loss of trust can be triggered by deterioration in the quality of bank loans. A second sub group indicates that financial crises are an integral part of business cycles. In such a context, economic agents have insufficient liquid asset to meet their liabilities and a crisis is triggered by errors in judgment by debtors and creditors.

The second school of thought focuses on causes of financial crises that are related to financial systems or to individual financial institutions. These authors emphasise fraud and irregularities in bank management as major causes of bank failures. Mismanagement, cutrate lending, aggressive liability management, blunders and lack of controls are considered major causes of bank failures.

Finally, some writers adopt a different view using both macro and micro economic elements to explain bank failures. According to them factors such as general macro economic conditions; real interest rates; disparity in regional economic growth and regulatory changes are causes of bank failures.

In the recent past there have been many financial crises. The causes of these financial crises are different. In the 19th and early 20th centuries, many financial crises were associated with bank runs, systemic banking crises and banking panics. Many recessions coincided with these panics (Kindleberger \& Aliber, 2005). Financial crises can be banking crises, international financial crises and wider economic crises (i.e., recessions and depressions). A situation where a commercial bank suffers a sudden rush of withdrawals by depositors is called a bank run. In such situations, banks cannot immediately fulfill the entire demand for money by the general public, because the bank may have invested its money in a variety of assets, gains of which may be realised during a long period of time. This may lead to a bank panic or banking crisis. Examples of bank runs were seen in the USA during 1931. An international financial crisis may occur when a country is suddenly forced to devalue its currency because of a speculative attack. This may be referred to as a currency crisis or a balance of payments crisis. Likewise, when a country fails to pay back its sovereign debt, 
it is referred to as a sovereign default. A balance of payment crisis along with a sovereign default can lead to a sudden stop in capital inflows or a sudden increase in capital flight. During 1992 - 1993, some countries in Europe faced this type of an international financial crisis. Further, there were international financial crises in many Latin American countries, when they defaulted their debt repayment in early 1980s. A wider economic crisis may consist of a recession or a depression.

A slowdown in economic growth for a continuous period is usually called a recession. A prolonged recession may be referred to as a depression. Since these phenomena affect much more than a financial system, they are not usually considered financial crises per se. The Great Depression in the 1930s is an example for a depression. Similarly, the recent sub-prime mortgage crisis and the real estate bubble experienced around the world starting in 2008 led to a recession in the US and in a number of other countries.

\section{Causes of Financial Crises}

The causes of financial crises vary depending on their nature. The following provides some of the causes of financial crises that can be identified from the recent history of a series of crises that occurred in different countries. Sometimes, recognition of only one cause of the crisis may be difficult as a crisis may take place as a result of many causes.

\section{(a) Macroeconomic Circumstances}

Adverse macroeconomic developments are blamed for financial crises. The trigger of a financial crisis may be due to errors in macroeconomic policies adopted by relevant authorities. High interest rates, shift of exchange rate regimes and unnecessary slowdowns or sharp increases in inflation are some of the macroeconomic reasons to trigger a crisis. High interest rates may attract more capital flows which may be for a short duration and could therefore be destabilising. High interest rates which may create difficulties for financial institutions and for governments, and over-valuation of exchange rates may lead to a financial crisis. When countries are unable to maintain exchange rates, they automatically try to shift into different exchange rate regimes causing imbalances in the external sector. Examples of these can be seen during the Mexican crisis from 1995 to 1957 and the South-East Asian crisis from 1997 to 1998. Instability in prices for a continuous period will cause uncertainties among economic agents in an economy and may lead to financial crises.

Prolong deficits in the current accounts may lead to unstable macroeconomic conditions in an economy creating financial crises. Countries which have budget deficits will have problems in financing their budgets, mobilizing savings and debt management. 
The Mexican Crisis during 1995-97 was brought about by deficits in the current account of the Balance of Payments (BOP), while the South East Asian Crisis was partly due to capital flight. Shifting of exchange rate regimes and high short-term borrowings created instability in these countries and led ultimately to capital flight causing a financial crisis.

High dependency on short-term foreign finance by way of borrowings or investment can lead to a financial crisis if there is a sudden withdrawal of short term foreign finance which is on lending or short-term investment. The crisis in the South East Asian countries was an example for this type of crisis.

\section{(b) Supervisory Concerns}

In most countries, the supervisory role of financial institutions is vested with the Central Banks or monetary authority. Weaknesses in supervisory activities, either due to insufficient legal framework or weaknesses in supervision, may not detect the problems of financial institutions early. This type of supervisory failures may lead to downfall of one or many financial institutions. This in turn could affect the entire financial sector and result in a financial crisis. Sometimes, financial institutions may attempt to conceal information from the supervisors in order to obtain short term advantages and it may lead to a crisis in the long-run. There are instances where some financial institutions have adopted the practice of keeping separate data sets, in an attempt to avoid tax payments. This may give a short-term financial benefit to financial institutions but in the long run it leads to a failure, which is a common cause for failure of financial institutions in emerging markets. Examples for these types of financial crises can be found in Sri Lanka where several finance companies failed during 1988-89. Anton Valukas, the court appointed examiner into Lehman's bankruptcy, produced a magisterial 2,200 page report last year of the bank's systematic failures of risk management and governance (The Economist, 2011, February 05). Perhaps best of all is a concise, confessional report issued by the Union Bank of Switzerland (UBS), in April 2008 into the failures of management that led it to take billions of dollars in write-offs and turned to the Swiss taxpayers for help.

\section{(c) Other Reasons}

Credit delivery is an essential activity for the survival of financial institutions. In addition to credit granted by financial institutions expecting benefits there may be credit extended in response to government directions. Excessive credit may create credit bubbles, the bursting of which may lead to failure of financial institutions. Sudden withdrawals of bank credit will develop serious situations where the borrowers 
are unable to repay the credit they obtain. The credit crunch in the US during 2007-2009 was one of the causes that led to a financial crisis and extended to a global financial crisis. Many leading financial institutions in the US failed during the crisis in 2007-2009 as a result of their inability to recover the loan repayments.

Government directions manifested by political reasons can lead to a financial crisis. For instance, sub-prime mortgage crisis in the US was created partly as a result of an oversupply of construction which was encouraged by government directions. The credit extended this way for house building led to an oversupply of houses resulting in a drop in the prices and creating difficulties for financial institutions to get their loans recovered. This led financial institutions to become insolvent and collapsed. Fanie Mea, Freddie Mac, and several other financial giants in the US failed due to these developments.

Financial products, if managed properly, would help to develop financial markets. However, an expansion of sophisticated financial derivatives beyond the safety levels may lead to a collapse of financial markets. One good example is the financial crisis in the US for which sophisticated and unmanageable derivative products are partly responsible. In this market new derivative products erupted based on sophisticated technology that ended up with complications and ultimately lead to a financial crisis.

In several countries, financial crises have occurred due to political developments. The Mexican Crisis occurred partly due to political reasons. The assassination of political leaders in that country created financial sector chaos and resulted in a withdrawal of short-term foreign finance due to fear of subsequent political developments.

Undue developments in the debt market, particularly in government debt, are one of the common causes of financial crises for which there are examples from many countries. During 2010-11 failures in Greece, Ireland and several European countries occurred due to excessive levels of public debt. Sometimes excessive borrowings have taken place in these countries for political purposes. Several of these countries were bailed out by supporting schemes of the IMF.

The foregoing explanation supports the fact that financial crises may occur due to one or a series of causes. Numerous examples for financial crises can be found from the history of different countries. At the initial stage, one or several causes would initially adversely affect one sector such as commercial banking which would impact other sectors creating worse situations. Sometimes, a crisis that occurred in one country may result in a crisis in other countries. For instance, the South-East Asian financial crisis initially started in Thailand and spread to neighbouring countries subsequently. Therefore, a contagion effect is also a cause for a financial crisis. The US crisis 
subsequently spread to most of the other countries in the world. Therefore, depending on the severity of the crisis in one country there would be global effects.

A number of authors have attempted to rationalise the causes of financial crises, especially looking at the background of recent financial crises. The following are ten most important causes of crises, particularly referring to the recent US crisis (Heath, 2011).

(1) Loose, ultra-interventionist monetary policy from central banks that kept stepping in whenever growth slowed or the stock market fell. Interest rates were kept too low; the belief was that as long as consumer prices didn't surge, the economy would be stable. The money supply and credit exploded, and investors became complacent, fuelling bubbles.

(2) Global imbalances, exacerbated by government intervention: nationalized savings, forex manipulation and sovereign wealth funds in China, Japan and the Middle East, combined with unfunded state pensions and profligate governments in the West brought about crises. Asia did all the saving and financed budget and trade deficits in the West, which spent too much and didn't produce enough. Asia purchased trillions of Western assets, especially bonds, pushing down yields and pumping the world full of cheap money.

(3) There was no bankruptcy code for failed multinational banking groups. Regulatory stupidity meant that they were treated like ordinary firms: the choice was either a collapse, or a bail-out. Other network industries - airports, nuclear plants - have long operated under special bankruptcy codes, ensuring an orderly winding-down and handover of assets. Unlike every other private businesses big banks knew they would never be allowed to go bust. So they took too many risks and leveraged themselves to the hilt to maximize returns on capital (and hence profit and pay); while lending criteria were slowly relaxed.

(4) Bondholders knew they would be bailed out. This meant that shareholders had access to cheap, state-insured credit. This promoted leverage to maximize upside; debt holders didn't care.

(5) Depositors knew they would be bailed out by the state and therefore didn't monitor banks' soundness. Property investors convinced themselves that prices would never fall. Financially illiterate consumers borrowed recklessly.

(6) Intellectual errors concerning the modeling of risk, the power of diversification, default chances, complete markets, liquidity and the existence of bubbles were widespread. These were caused by the neo-classical general equilibrium paradigm prevalent in universities, central banks and the private sector. 
(7) One result of (6) above was that firms were forced to follow mark-to-market accounting rules. Liquidity problems became a solvency crisis.

(8) As a result of (3) and (7) above, institutions held insufficient capital and the wrong kind of capital: a problem compounded by off-balance sheet vehicles. These arrangements were all approved of by international regulators, the Basel accords and accounting rules.

(9) US politicians' promotion of homeownership among groups was shunned by lenders. This involved legislation and the use of the state-chartered Fannie Mae and Freddie Max to promote and securitise sub-prime mortgages. While dodgy loans were eventually embraced by Wall Street, their origin lay in Washington.

(10) Other errors: AIG misused credit default swaps and writing insurance against losses, yet did not keep enough capital to make good on its promises. Credit rating agencies - whole number was limited by regulators - failed miserably.

\section{Some Examples of Financial Crises}

The following are some examples of recent financial crises.

\subsection{The Argentinean Banking crisis of 1980-82}

In 1980, a failure of one of the largest private banks in Argentina created a root for a financial crisis. This led to a series of crises of Argentina's financial system which resulted in 71 financial institutions being liquidated in 1980-1982 with consequences not only to the financial system but also to overall economic policies. Several economic elements prevailed during that time, the weaknesses in bank supervision, high interest rates for both deposits and lending, weaknesses in the macroeconomic policies and business failures were highlighted as causes of such financial crisis.

It was observed that 16 per cent of assets of commercial banks and 35 per cent of total assets of finance companies were affected due to this crisis. The Central Bank/government was able to contain the propagation of the crisis by implementing various measures.

\subsection{The Chilean Banking Crisis during 1981-83}

The Chilean banking crisis is one another widespread crisis, aggressively handled and having positive results later on. The origins of the banking crisis in Chile 
were related largely to the severe macro economic problems experienced by the country and Latin America specially, during 1981-1982. Weaknesses in liberalization policies, increase in inflation to unmanageable levels, foreign currency management problems, enhanced trade deficit and increased debt were some of the macro economic causes which created the crisis.

By the end of 1982, a macro economic crisis was apparent and banks became insolvent. In 1983, government intervened in the insolvent institutions and immediately liquidated some of the banks which experienced problems while implementing debt relief measures, the purchase of risky loans by the Central Bank, recapitalization of intervened banks and implemented thorough supervisory and prudential regulations which were successful in handling Chilean banking crisis.

\subsection{The Mexican Economic Crisis during 1995-97}

The Mexican economic crisis is another one that took place during the 1990's. There are opposing views among the analysts about the origin of this economic crisis. Weaknesses in managing exchange rates which led to exhaust Mexican foreign exchange reserves, political uncertainties, weaknesses in debt management and fiscal monetary policies were some of the causes highlighted to this crisis.

This financial crisis was resolved by implementing many strategies. Mexican Government's last resort loans along with deposit insurance system to reassure foreign investors were helpful in recovering from the crisis. Government also took initiatives to afford long term liabilities by way of issuing long-term bonds. The switch onto a flexible exchange rate regime was also another solution.

\subsection{The Asian Financial Crisis in 1997-98}

The Asian financial crisis occurred in a number of countries beginning in July, 1997. The crisis started in Thailand with the collapse of the Thai Baht caused by the decision of the Thai government to float the Baht, cutting its peg to the US dollar, after exhaustive efforts to suppress it in the face of a severe real estate bubble. Indonesia, South Korea and Thailand were the countries most affected by the crisis. Hong Kong, Malaysia, Laos and the Philippines also had contagion effects of the slump. China, India, Taiwan, Singapore, Brunei and Vietnam were less affected. The political leadership in Thailand and Malaysia was forced to step down as a result of the crisis. 
Initially, Thailand's economy developed into a bubble fuelled by "hot money". The same type of situation happened in Malaysia and Indonesia too.

Availability of a large amount of credit based on short-term capital inflows generated a highly leveraged economic climate and pushed up asset prices to an unsustainable level. These asset prices eventually began to collapse, causing individuals and companies to default on debt obligations. The resulting panic among lenders led to a large withdrawal of credit from the crisis countries, causing a credit crunch and further bankruptcies causing investors to withdraw their money, thus putting depreciation pressure on their exchange rates. Accordingly, the crisis happened due to withdrawal of foreign finance from the crisis driven countries. Ultimately, the effects of the crisis ended by IMF's bailout package for most affected economies and advocating reforms to the Asian currency, banking, and financial systems. The IMF's support was conditional on a series of economic reforms under a financial supported scheme called "Structural Adjustment Package", (SAP).

\subsection{The US Sub-prime Mortgage Crisis Starting from 2007}

The US sub-prime mortgage crisis was one of the worst hit and recent financial crises. The crisis began with the bursting of the United State's housing bubble and high default rates on "sub-prime" and adjustable rate mortgages, beginning in approximately 2005/06. In the US, borrowers are rated either as "prime" or as "sub-prime". The prime borrowers have a good credit rating based on their track records while sub-prime borrowers have track records in repaying loans below par. Loans given to sub-prime borrowers are categorized as sub-prime loans. Typically it is the poor and the young who form the bulk of sub-prime borrowers.

A major contributory factor for the attractiveness of the sub-prime loan market was the boom in the supply of housing, which resulted in falling prices and increase in the default rate among sub-prime borrowers, many of whom were no longer able to repay their loans. Another factor was the collateral for the houses, which in US was typically the home being bought, and which increased the supply of houses for sale while there was a low demand which resulted in declining house prices. This coincided with the slow down in the US economy making matters worse.

The repayment capacity of sub-prime borrowers was in any case doubtful. Further, lenders devised new sophisticated instruments, such as derivative products to reach out to more sub-prime borrowers. The links of complex derivative products on the loan portfolios were very complicated. Therefore, there were more doubts about the ultimate re-payers. 
Not only the reckless lenders, but also big institutions such as, Freddie Mac and Fannie Mae, which owned or guaranteed more than half of the outstanding in home mortgage in the US and widely thought as being more prudent than others in their lending practices suffered billions of losses. The crisis affected institutions such as Citigroup and Merrill Lynch which are global banks and brokers who had to write-off billions of sub-prime losses. Despite efforts by the US Federal Reserve to offer some financial assistance, crisis led to the collapse of Bear Sterns, one of the world's largest investment banks and securities trading firms. The crisis also extended to Lehman Brothers, and American Insurance Group.

The crisis affected not only these American institutions but also too many banks in other parts of the world. Since the US was the biggest borrower in the world, most countries which held their foreign exchange reserves in dollars and invested in the US Securities were badly affected. Countries like Japan, China and India that had invested in the US had direct adverse impacts from this crisis. Also the global equity markets got hit from this crisis. Other than these, countries which had trade links with the US were affected due to down-turn in the US. Therefore, the effects of the US crisis were not only limited to the US economy, but also to the global economy.

\subsubsection{Consequences of the US Crisis}

As a result of the mortgage crisis, lenders in the US were unable to recover their loans. A number of financial institutions collapsed, and businesses of many non-financial institutions, such as car producers, garment sellers and food sellers faced difficulties in selling their products. Consumer prices in Advanced Economies, as identified by the IMF, grew only by 0.1 per cent in 2009. Mortgage giants such as, Fannie Mea and Freddie Mac were affected extensively. The fourth largest investment bank in the US, Lehman Brothers, Wall Street's fifth largest bank Bear Stearns, which was acquired by another organisation, and Merrill Lynch collapsed. A number of financial institutions declared bankrupt, merged, acquired by other organizations, bailed out by the governments or were nationalised. An Insurance major, American Insurance Group, was also under severe pressure and collapsed. Not only the US, but also in the other countries in the Euro banking sector, a number of financial institutions as well as producing firms collapsed due to the crisis in US. For instance, Northern Rock and European Banking and insurance giant Fortis were partly nationalised to ensure their survival. General Motors (GM), the car producing firm in the US and Mark \& Spencer were faced with declining sales. 
Rating Agencies downgraded their investment ratings of a number of financial institutions. Industrial production in many countries dropped and as a result world industrial production dropped (Figure 1).

Figure 1

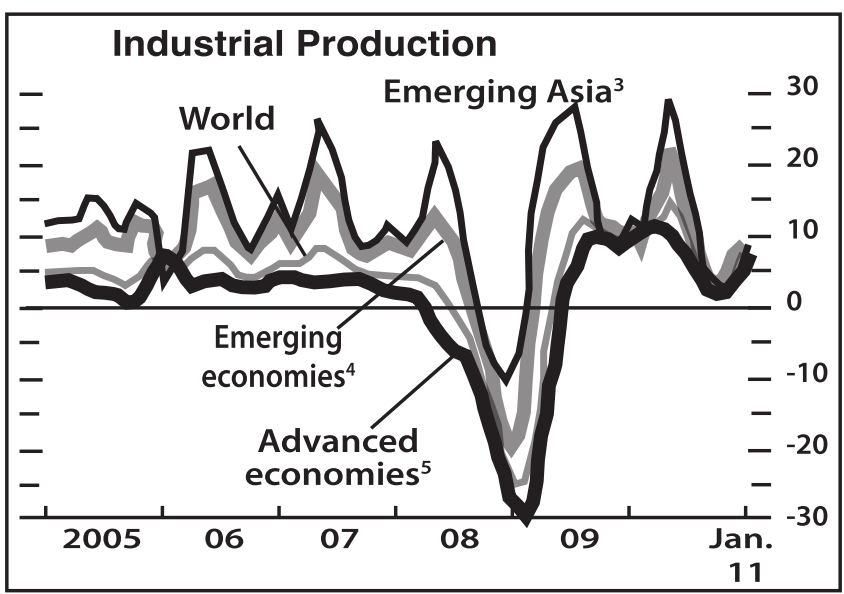

Source : IMF World Economic Outlook 2011

Figure 2

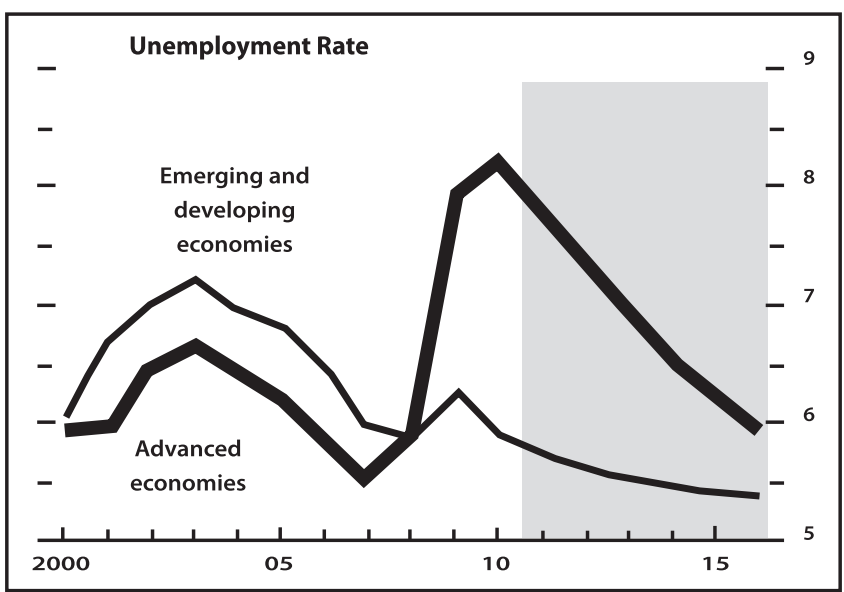

Source : IMF World Economic Outlook 2011 
Unemployment surged and employment growth was negative in several countries (Figure 2). Unemployment in Advanced Economies (as classified by the IMF) increased by 8 per cent in 2009. The Chief Executive Officers of several banks (Citi Group and Merrill Lynch) stepped down.

The World Bank and the IMF predicted slow rates of economic growth in the richest nations and globally. Current Account balances in a number of advanced countries became negative. Countries suffered due to lack of demand for their goods and services and fell into a recession. Prices of houses and goods and services fell. The stock markets suffered with fallen prices and collapsed (Figure 3). A US recession was officially declared by the National Bureau of Economic Research, a leading panel including economists from major academic institutions. The Figures indicated that more US workers lost their jobs in 2008 than any year since the World War II. The US, UK and many other European countries suffered negative growth in 2008. The growth of world output too became negative (-0.5 per cent), (IMF World Economic Outlook, 2011).

Figure 3

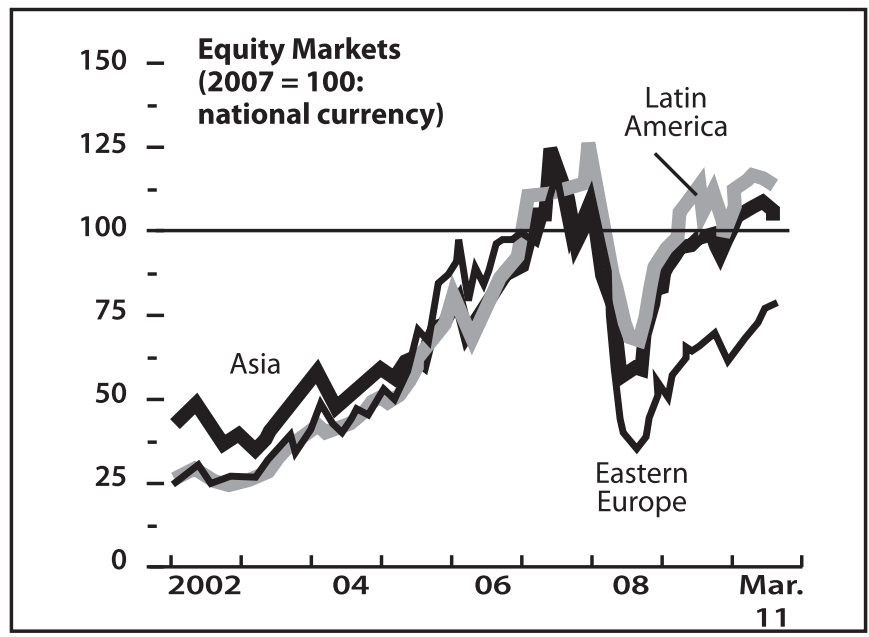

Source : IMF World Economic Outlook 2011

Not only the US and European economies suffered but also other countries such as China, Japan and India faced their biggest decline in exports. This was common to other exporting countries in Asia and Africa. IMF warned that the 
world economic growth was to fall to just 0.5 per cent in 2009 . However, world output in 2009 grew by -0.6 per cent. The International Labour Organisation predicted that as many as fifty one million jobs worldwide could be lost in 2009 because of the global economic crisis.

\subsubsection{Responses to the Crisis}

Various actions were taken by the authorities of many countries (as named in Table 1) since the crisis became apparent in August 2007. These solutions vary from country to country. The Bank for International Settlements (BIS) has summarised, as given below, the different policies suggested by many countries to tackle the issues that arose from the US crisis.

Table 1

Policy Measures adopted by Countries

\begin{tabular}{|c|c|c|c|c|c|c|c|c|c|c|c|c|c|c|c|c|c|}
\hline \multicolumn{18}{|c|}{ Summary of policy actions taken in North America, Europe, Asia and the Pacific ${ }^{1}$} \\
\hline & CA & us & EU & $\mathrm{CH}$ & UK & $\mathrm{AU}$ & $\mathrm{CN}$ & HK & $\mathbb{I N}$ & ID & $\mathrm{JP}$ & KR & MY & NZ & $\mathrm{PH}$ & SG & $\mathrm{TH}$ \\
\hline Ease monetary policy & $\sqrt{ }$ & $\sqrt{ }$ & $\sqrt{ }$ & $\sqrt{ }$ & $\sqrt{ }$ & $\sqrt{ }$ & $\sqrt{ }$ & $\sqrt{ }$ & $\sqrt{ }$ & $\sqrt{ }$ & $\sqrt{ }$ & $\sqrt{ }$ & $\sqrt{ }$ & $\sqrt{ }$ & $\sqrt{ }$ & $\sqrt{ }$ & $\sqrt{ }$ \\
\hline Introduce fiscal stimulus & & $\sqrt{ }$ & $\sqrt{ }$ & & $\sqrt{ }$ & $\sqrt{ }$ & $\sqrt{ }$ & $\sqrt{ }$ & $\sqrt{ }$ & $\sqrt{ }$ & $\sqrt{ }$ & $\sqrt{ }$ & $\sqrt{ }$ & $\sqrt{ }$ & $\sqrt{ }$ & $\sqrt{ }$ & $\sqrt{ }$ \\
\hline Liquidity assistance in local currency & $\sqrt{ }$ & $\sqrt{ }$ & $\sqrt{ }$ & $\sqrt{ }$ & $\sqrt{ }$ & $\sqrt{ }$ & & $\sqrt{ }$ & $\sqrt{ }$ & $\sqrt{ }$ & $\sqrt{ }$ & $\sqrt{ }$ & & $\sqrt{ }$ & $\sqrt{ }$ & $\sqrt{ }$ & \\
\hline Lend foreign exchange & $\sqrt{ }$ & & $\sqrt{ }$ & $\sqrt{ }$ & $\sqrt{ }$ & $\sqrt{ }$ & & $\sqrt{ }$ & $\sqrt{ }$ & $\sqrt{ }$ & $\sqrt{ }$ & $\sqrt{ }$ & & $\sqrt{ }$ & $\sqrt{ }$ & $\sqrt{ }$ & \\
\hline Expand deposit insurance & & $\sqrt{ }$ & $\sqrt{ }$ & & $\sqrt{ }$ & $\sqrt{ }$ & & $\sqrt{ }$ & & $\sqrt{ }$ & & $\sqrt{ }$ & $\sqrt{ }$ & $\sqrt{ }$ & $\sqrt{ }$ & $\sqrt{ }$ & $\sqrt{ }$ \\
\hline Guarantee non-deposit liabilities & $\sqrt{ }$ & $\sqrt{ }$ & $\sqrt{ }$ & & $\sqrt{ }$ & $\sqrt{ }$ & & & & & & $\sqrt{ }$ & & $\sqrt{ }$ & & & \\
\hline Prepare bank capital injection & & $\sqrt{ }$ & $\sqrt{ }$ & $\sqrt{ }$ & $\sqrt{ }$ & & $\sqrt{ }$ & $\sqrt{ }$ & $\sqrt{ }$ & & $\sqrt{ }$ & $\sqrt{ }$ & & & & & $\sqrt{ }$ \\
\hline Create demand for assets & $\sqrt{ }$ & $\sqrt{ }$ & $\sqrt{ }$ & $\sqrt{ }$ & $\sqrt{ }$ & $\sqrt{ }$ & $\sqrt{ }$ & & $\sqrt{ }$ & $\sqrt{ }$ & $\sqrt{ }$ & $\sqrt{ }$ & $\sqrt{ }$ & & & & \\
\hline Impose short sale restrictions & $\sqrt{ }$ & $\sqrt{ }$ & $\sqrt{ }$ & $\sqrt{ }$ & $\sqrt{ }$ & $\sqrt{ }$ & & $\sqrt{ }$ & & $\sqrt{ }$ & $\sqrt{ }$ & $\sqrt{ }$ & & & & $\sqrt{ }$ & \\
\hline Relax mark to market rules & & $\sqrt{ }$ & $\sqrt{2}$ & $\sqrt{ }$ & $\sqrt{ }$ & & & & & $\sqrt{ }$ & $\sqrt{ }$ & $\sqrt{ }$ & $\sqrt{ }$ & & $\sqrt{ }$ & & \\
\hline \multicolumn{18}{|c|}{$\begin{array}{l}\mathrm{CA}=\text { Canada; } \mathrm{US}=\text { United States; } \mathrm{EU}=\text { Euro area; } \mathrm{CH}=\text { Switzerland; } \mathrm{UK}=\text { United Kingdom; } \mathrm{AU}=\text { Australia; } \mathrm{CN}=\mathrm{China} \\
\mathrm{HK}=\text { Hong Kong } \mathrm{SAR} ; \mathrm{IN}=\text { India; ID = Indonesia; JP = Japan; } \mathrm{KR}=\text { Korea; } \mathrm{MY}=\text { Malaysia; NZ = New Zealand; } \mathrm{PH}=\text { Philippines; } \\
\mathrm{SG}=\text { Singapore; } \mathrm{TH}=\text { Thailand. }\end{array}$} \\
\hline 'As of July 2009 . This table sumn & & & & & & & & & & & & & & & & & \\
\hline
\end{tabular}

Source : Bank for International Settlements

It is to be noted that US, the UK, the Euro Zone and Japan used unconventional monetary policies which are known as Quantitative Easing (QE) to stimulate their economies when conventional monetary policy has been ineffective. Under 
these the central banks continued to buy government bonds and other financial assets, with new money created, in order to increase money supply and the excess of reserves of the banking system. QE shifted monetary policy instruments away from interest rates, towards targeting the quantity of money. QE used to expand the excess reserves in the banking system and lowering interest further.

The following are details of some of the measures adopted by different countries to overcome the effects of the US crisis.

\subsubsection{Monetary Policy Actions}

The central banks as regulators implemented monetary policy measures to remedy the crisis since the crisis involved banks and financial institutions. Federal Reserve (Fed) of the US slashed interest rates in December 2008 to zero which was the lowest. In January 2009, Bank of England cut interest rates to a 315 year lowest of 1.5 per cent. In March 2009, the European Central Bank cut their bench mark interest rates to the lowest level ever. In September 2008, China cut its interest rates for the first time since 2002. India too started cutting down interest rates. Other than interest rates cut under the monetary policy, Fed and other central banks have conducted open market operations to ensure member banks have access to liquidity. Under these programmes, the Central Bank made available short-term loans to member banks under collateral of government securities. Also the frequency of conducting auctions was increased by certain central banks. Some other measures, such as inclusion of commercial papers as collateral for loans were also implemented to address the liquidity concerns.

\subsubsection{Legislation and Regulatory Arrangements}

Other than monetary policy measures legislation relating to lending practices, bankruptcy protection, tax policy, housing, credit counseling, education, and licensing of lenders were drafted or amended by countries including the US. Especially, the US government considered amending the regulatory powers of the Fed. Legislation relating to exemption of non-depository banks from capital reserve requirements and legislation for the companies to not become "too big to fail" were also suggested by eminent economists like Joseph Stiglitz (Recommendations of the Stiglitz Commission on Finance, 2009). The UK regulator announced a temporary ban on short sales of financial stocks. The Australian Federal government announced an investment of funds in non-bank lender mortgaged backed securities. The then US President, George 
Bush signed a law for economic stimulus package to help stimulate economic growth. The US also took action to pass Housing and Economic Recovery Act of 2008 to restore confidence in the domestic mortgage industries. This act included provisioning of insurance, establishing a new regulator, raising limits of mortgages, provision of loans for the refinance of mortgages, enhancing mortgage disclosers and extending community assistance to help local governments to buy foreclosed properties. Federal courts were flooded with a number of cases, some of which were to claim compensation from different financial institutions.

\subsubsection{Government Bailouts}

Countries such as the US and UK introduced a series of government bailouts for the institutions which failed. The Fed took-over Freddie Mac and Fannie Mae. Bear Stearns was acquired by J P Morgan Chase. Merrill Lynch was acquired by Bank of America. Lehman Brothers declared bankruptcy. The Fed provided emergency loans to AIG Washington Mutual. In the UK, Northern Rock faced difficulties and approached the Bank of England which was the lender of the last resort. Ultimately, Northern Rock, Bradford \& Bingley, a British bank was nationalized by the UK government.

In addition to above, the US government announced plans to purchase large amounts of illiquid risky mortgage backed securities from financial institutions. Several governments initiated action to get approvals from their national legislatives to extend bailouts amounting to billions of dollars as a measure to tackle the crisis. The US government approved a dollar 700 billion rescue plan for the US financial system in 2008. Other countries, such as UK and Germany approved bailout packages for the financial institutions in their countries. Other than the individual countries, the IMF also approved loan facilities amounting to trillion dollars to many Western European countries, being the first IMF loan for some of the European countries since 1976. In November 2008, the US Fed announced an injection of another dollar 800 billion into the economy to stabilize the financial system and encourage lending. In the same month, the European community unveiled an economic recovery plan worth of 200 billion Euros to protect millions of European jobs. Several Asian countries took action to establish bailout packages for financial institutions. Some financial institutions obtained new capital from their governments. In order to facilitate the growth of small businesses European banks increased the amount of loans to small and medium sized enterprises. Australian Federal government also announced packages worth billions of dollars. India increased 
refinance schemes in billions of dollars. Bank of Japan injected billions of dollars into its financial systems.

Other than the above measures, a number of regulatory measures and accounting standards were also proposed by many countries. Awareness programmes, moral suasion and other measures were taken by the governments and central banks as measures to reduce the adverse impacts of the crises.

\subsubsection{Combined Policy Actions}

The Federal Reserve Bank, the European Central Bank, the Bank of England, the Bank of Japan, the Bank of Canada, the Swiss National Bank and the Swedish Riks Bank announced measures to release liquidity to financial institutions while simultaneously reducing policy interest rates. These banks also eased the credit conditions in the non-bank sector. Central banks in emerging economies too started a number of measures and bail-out packages for their financial institutions. Provision of foreign currency liquidity to foreign exchange markets helped to protect the decline in domestic currencies. A series of macroeconomic policy measures was also implemented in tandem with monetary policy measures implemented by affected countries.

\section{Lessons from the Financial Crises}

As described above, financial crises are not new to the world. They have occurred throughout history. These financial crises have taught many lessons to the regulators, governments, financial institutions and to the general public at large. In spite of many lessons learnt from the historical financial crises, financial crises have occurred repeatedly. The lessons learnt may be of macro or micro importance. Some argue that in order to avoid financial crises solutions should be tried. Conversely, Alan Greenspan, the US Federal Reserve's previous chairman, suggests that no one should try any action and says that things went well over the long period of deregulation and light-touched oversight, while arguing that the global financial system is now "unredeemably opaque" that policy makers and legislators cannot hope to address its complexity. However, some argue that Greenspan is wrong and crisis that threatened the foundation of the American economy, led to soaring unemployment, a continuing foreclosure crisis and weakened economies in the US and Europe. It would have been a grave mistake not to address problems of inadequate regulation and lax oversight (Barney Frank, 2009). Hence, the arguments for and against actions to be taken to prevent financial crises are different. 
Based on these crises, the following lessons can be highlighted for regulators and financial institutions in order to overcome or at least to reduce adverse impacts from possible crises.

- Many financial crises have taught the necessity of strengthening regulations to tackle the behaviour of financial institutions. From the US crisis, it was emphasized that regulations are required to tackle institutions that are too big to fail. From the recent financial crisis, it appears that the weaknesses in regulatory mechanisms fueled failed financial institutions and led to a financial crisis which had wider repercussions. The regulations are required not only to regulate financial institutions but also to regulate new products such as derivatives, to evade troubles. Further, these laws increase transparency through new financial services that will give powers to regulators to access information about the entire financial system. The mechanisms such as Basel II, Basel III etc. also have imposed some capital requirements which will ensure the stability of institutions. These mechanisms are ex-ante preventive measures anticipating possible weaknesses in advance. However, some may argue that these regulations may impose controls preventing the liberalization philosophy.

- Krugman (2000) argues that poor economic "fundamentals" also can be a reason for the Asian financial crisis. It was said that nations exposed themselves excessively to speculative movements of capital and short term capital flows, with no regulations and controlled mechanisms set up in advance. This was purely because of the prevailing philosophy of openness to all kinds of financial flows. Therefore, regulators have to be careful. The fact is that Asia became very dependent on foreign investors whose concern was not whether a country had its fundamentals in order but what other speculators were thinking. This created a very volatile structure and ultimately a chain reaction of crises. Short-term foreign borrowing increases vulnerability to shocks. The short term flows coming in can quickly flow out. Thailand was an example for this where withdrawals of short-term finances created the financial crisis in South East Asia. At present, the IMF supports imposition of controls on short term finances.

- The crises have taught us the necessity of proper macroeconomic management. In that, controlling inflation, prudent exchange rate management, deficit financing management have been shown to be of great importance. Some small economies such as Singapore and New Zealand have both liberalised capital accounts and floating exchange rates under their macro-economic framework. Accordingly, under macro-economic management proper external and internal economic management has to be in place to avoid crises.

- Crises which led to a reduction of expenditure of households ended up with recessions. When there is a crisis, restrictions in the monetary side and credit will take place, resulting in a decline in demand for goods and services. These measures may impose 
restrictions on small and medium-sized enterprises. The US crisis, which provides an example, led to a reduction in consumption of the households and resulted in a drop of demand for goods and services produced by firms. This ultimately led to a world-wide crisis, adversely affecting exports of emerging economies while it created a recession in many countries including USA and the UK.

- Another lesson that can be learnt is the avoidance of overreaction to short-term domestic and external developments. For instance, Korea at end of 1997 experienced an unanticipated sharp exchange rate devaluation that triggered an unprecedented banking crisis. Therefore, in monetary and fiscal management countries have to consider long term perspectives rather than short term goals. Long term policies would contribute to maintain stability avoiding rooms for crises.

- The effects of the crisis are long term and costly. Many countries happen to spend a lot of tax payers' money to rescue failed financial institutions. This was clear from the US crisis when billions of dollars were pumped from the government to bail out failed institutions. This was not limited to the US, but also to many countries in the world that came up with financial assistance from the governments to rescue financial institutions both in the government and the private sectors. Even in Sri Lanka during the period where there was a distress in financial companies, the government (central bank) extended financial assistance to rescue finance companies from collapsing, an activity that had a cost.

- It is required to have sufficient supervision and adequate public disclosures to prevent the failure of financial institutions. Strong supervisory measures have been implemented by many countries which faced the adverse impacts of crises while countries such as US and those in G20 came up with strong legislation in order to strengthen supervision. Financial institutions should respond to this supervision favourably to prevent possible collapses. Even in Sri Lanka prudential supervision and timely action on financial institutions protected the country from the adverse effects of the several crises that occurred around the world. Because of the strong supervision and timely measures implemented in Sri Lanka, the country was able to protect itself from adverse effects of the South-East Asian and US crises. The Korean financial crisis in 1997 was due to lax provisioning, poor standard of concentration of risk and large exposures, lack of good internal liquidity management controls, and weaknesses in supervision and regulatory arrangements. Therefore, financial institutions should respect supervision and regulatory arrangements to avoid future crises.

- Mechanisms such as Deposit Insurance Schemes to protect the depositors provide favourable grounds to avoid adverse effects of the crises. In 1996, Japan came out of a deposit insurance scheme. Steps that Sri Lanka undertook to establish a deposit 
insurance scheme may be a part of risk management, which provided authorities with improved flexibility to deal with failed financial institutions. The IMF has stated that world's largest and most important banks should pay additional fees to address the risk of liquidity shortfall in their institutions that may cause wider damage to the financial system.

- From the experience of crises a need has arisen for the private financial institutions to act proactively to regulators' actions in order to avoid adverse impacts. The perception that official resources can be used to bail out creditors generates moral hazards. It could lead to excessive risk taking by lenders and funding of less economically defensible projects and may aggravate the possibilities of crises. After the adverse experiences of the recent crisis in the US, regulators are considering imposition of regulations to limit gearing capacity, enhance capital adequacy, and to conduct stronger stress tests on financial institutions. The private sector responses to governments' or the regulators' actions are required to prevent crises.

- Financial Institutions, especially banks, should carefully arrange investment portfolios drawing attention to both liquidity assets and profit-generating assets to maintain public confidence which is very important for their functions. Liquid assets and profitgenerating assets have two ends, and their proper maintenance may ensure confidence of the public as well as profits of the financial institutions. The global financial crises have taught lessons emphasising the importance of maintaining a healthy financial system based on public confidence and generating profits.

- Financial crises have shown the importance of risk management for financial institutions. The US financial crisis in which a number of financial institutions failed due to poor risk management revealed the importance of this activity. The dealing with sophisticated derivative products which was the main cause behind the US crisis carried enormous risks to financial institutions. Therefore, financial institutions should pay greater attention to manage both current and future risks.

- One of the prominent characteristics behind financial crises has been the insufficient awareness of the financial products and activities of financial institutions. During the crises it was evident that the staff of the financial institutions as well as the general public did not have proper knowledge of the financial products. The general public usually goes for high returns without much consideration of the security of the assets thus creating substantial losses to the depositors. Therefore a greater awareness of the staff members of the financial institutions on various developments is also essential. A team of well-qualified and experienced staff is required for financial institutions for which training and capacity building are essential. 
- Some crises have erupted due to political reasons. The crises that occurred with this background have created unemployment and problems in income distribution resulting in changes in political environment. For instance, in Thailand, the Prime Minister was forced to resign and President Suharto in Indonesia stepped down after 32 years of autocratic rule. In South Korea the autocratic government of Kim Young Sam was replaced by relatively untainted regime of Kim Dae Jung. So, the lesson learnt from this is that a financial crisis may lead to a political crisis as well.

- Crises have shown the importance of international relationships. The crises such as in South East Asia and the US have proved the necessity of coordinated policy actions among major central banks to counter adverse effects of the crises. The US requested co-operation from Europe to tackle the financial crisis which had global repercussions. A number of countries in Europe responded to this request by adopting parallel monetary and fiscal policy measures. The European Central Bank, Bank of England, Bank of Japan, Bank of Canada, Swiss National Bank, and the Swedish Riksbank announced measures to release liquidity directly to financial institutions and reduction in policy rates. Therefore, to tackle a crisis, international co-operation is required. Corea (1998) argues that casualties of financial crises have come due to lack of North-South dialogue.

The above mentioned lessons can be treated as global lessons that we have learnt from the crisis situations. Sri Lanka was not adversely affected due to the recent crisis in the US because of an improved macroeconomic situation, favourable regulatory background, prudent supervision and the timely action taken by relevant authorities. Central Bank of Sri Lanka (CBSL) (Annual Report of the CBSL 2009, p.17) highlighted the necessity of global solutions, quick and decisive policy actions, long term view of policies, proactive communications, early implementation of necessary macroeconomic policies, forward looking risk management, strong regulatory and supervisory role, early recognition of global developments and implementation of package of policies rather than relying on one to avoid adverse impacts of crises.

\section{Financial Crises and the Sri Lankan Economy}

\subsection{Financial \& Economic Crises in Sri Lanka - The History}

So far, Sri Lanka has not faced a severe financial or economic crisis. However, the country has faced some difficult economic situations particularly in the finance sector. The banking crisis occurred in Sri Lanka during 1860s and 1870s 
required the intervention of the government to bail-out some affected banks (Karunatilake, 1986). Other than this crisis, no evidence is found to trace a noticeable financial crisis that has taken place in the history of Sri Lanka.

Several financial companies in the country collapsed during 1988 and 1989. The Central Bank of Sri Lanka responded to this crisis by extending financial support for distressed finance companies (CBSL Annual Report, 1989). Financial assistance was made available to finance companies in distress in order to pay the depositors. Some of the collapsed finance companies were closed and some were rehabilitated. However, this crisis was not widespread. Mismanagement and difficulties of portfolio management were identified as causes for the collapses.

The government's re-capitalization of State Banks, i.e., Bank of Ceylon, Peoples' Bank and the National Savings Bank in 1993 \& 1996 (Hemachandra, 2005, p.74) cannot be considered as a crisis situation but a step taken to strengthen government banks.

In addition to these situations there were several occasions that the country faced some hardships in regard to the country's balance of payments and fiscal management where the government and the central bank obtained financial assistance several times under the standby arrangement facility of the IMF to set the economy on the right path. Since 1965 , the first time that the country received IMF funds under this arrangement, there were seven other instances up to date when the government has sought financial assistance from the IMF to overcome difficult situations in Sri Lanka. The latest IMF assistance was obtained by Sri Lanka to resolve difficulties faced by the country in its international reserves which arose as a result of the US financial crisis. As a result, coupled with the decline in export earnings Sri Lanka's foreign reserve situation deteriorated and the country started to defend its exchange rates which the Sri Lanka rupee was pegged to US dollar. In this latest bail-out, which was similar to the procedures followed by most of the other countries in the world, Sri Lanka too obtained funds under the standby arrangement and the country was able to increase its reserve levels which helped to build the confidence of the international investors whose investment were expected. However, Sri Lanka's financial system stability was not affected due to the US financial crisis. Country was able to revive and to achieve a higher economic growth, i.e., 8 per cent in 2010 partly due to these measures. 


\subsection{US Financial Crisis and the Sri Lankan Economy}

In this section the impact of the US financial crisis on the Sri Lankan economy is analysed. It is analysed so as to show how the US crisis impacted on certain economic activities of the country. The US crisis was the latest financial and economic crisis which impacted on trade and economic growth of many countries including Sri Lanka.

There were adverse macro economic impacts arising from the US crisis on countries depending on their level of interactions with the global economy. In the case of Sri Lanka, because of the fact that the capital account has not been fully liberalized and that many local banks did not deal with complex financial instruments, the direct impact of the global financial crisis on the Sri Lankan economy was minimal. Due to the same reasons the contagion effect of the South-East Asian crisis was also minimal on the Sri Lanka economy. However, with the intensification of the crisis that has spilled over into the real sector of the economy, the effects of the US crisis was felt strongly in the Sri Lankan economy.

As a result of the financial crisis, many foreign investors who had invested in short-term investments repatriated their investments back to their countries for meeting rising liquidity requirements in their countries. The foreign funds which were invested in debt instruments, such as Treasury bills and long-term bonds in Sri Lanka were withdrawn from the country partly as a result of the global financial crisis. At the end of 2008, there was a sudden reversal of short-term capital inflows to Sri Lanka. The net outflow amounted to US \$ 213 million due to withdrawal of US \$ 430 million in the last quarter of 2008.

The demand for Sri Lankan exports, particularly apparel products declined substantially due to a slow down in the crisis-driven countries. This was a combined effect of the reduction in the global demand for Sri Lankan textile exports and stiff competitiveness among exporters. There was a decline in exports such as tea and rubber from Sri Lanka. The decline in exports was a result of the downfall in demand for these products from trading partners such as Middle East countries and Russia and decline in prices. The growth of textile and leather product category recorded a slow growth of 3.1 per cent in 2008 compared to 7.3 per cent in 2007 due to the downturn in the demand from US and European countries. Also the growth of industrial sector was low in 2008 compared to 2007. In addition, exports of rubber-based products, diamond and jewellery industries were also affected due to the decline in demand. In order to avoid some of the adverse effects, the government had to unveil an economic stimulus package. 
In the meantime, some local industries resorted to short-term lay-offs of workers as a result of the depressed demand for export products. The services sector growth also declined from 7.1 per cent in 2007 to 5.6 per cent in 2008 (Annual Report of the CBSL, 2008).

Another sector affected due to global crisis was the tourism sector. Tourist arrivals dropped by 11.2 per cent in 2008 partly due to the global crisis (Annual Report of the CBSL, 2008). The tourist arrivals from the Western Europe and North American countries dropped by 15 per cent in 2008 when compared to 2007.

The decline in export earnings and withdrawal of short-term investments by foreigners, particularly in the government securities market, resulted in a balance of payments difficulty in Sri Lanka. The high growth of imports and lower growth of exports too contributed to expand the trade deficit in 2008. As a percentage of GDP, the trade deficit deteriorated from 11.3 per cent in 2007 to 14.4 per cent in 2008. As a result of these developments, the balance of payments which recorded a surplus of US $\$ 515$ million as at end of July 2008 turned into a deficit of US \$ 1,225 million at the end of 2008 (Figure 4).

Figure 4

Balance of Payment Position



Source : Central Bank of Sri Lanka

The increase in the value of imports was further intensified due to an increase in the prices of imports, particularly of petroleum. Owing to slow growth of exports and low demand for exports from the Western Countries that resulted from the crisis contributed to this adverse impact on reserves and thereby to build a 
pressure on the exchange rate to devalue. The central bank sold its foreign reserves to protect the exchange rate from devaluation. At the end of 2008 total external official reserves dropped to US $\$ 1,594$ million indicating reserves were sufficient to finance only 1.4 months of imports although accepted number is 3 months. This depletion of reserves, coupled with decline in export earnings prompted the policy makers to search for mechanisms to increase the level of reserves.

Crisis in the US and its contagion effects in western countries required Sri Lanka to change its external portfolio investments to minimise risks. The CBSL had to take a concerted effort to manage its investments of foreign reserves by changing strategies and shifting them into safer destinations. This was required for minimising risks while at the same time increasing returns.

The impact of the global crisis through the channels as explained above ultimately resulted in a slow rate of economic growth in Sri Lanka. The impact on economic growth due to crisis and recession in the world was severely felt during last quarter of 2008 and first half of 2009. The GDP growth dropped to 4.3 per cent in Q4 of 2008 compared to 6.3 per cent in Q3 and 7.0 per cent in Q2 of 2008. The lowest economic growth of 1.6 per cent in the first quarter 2009 indicated the adverse effects of the global crisis on the Sri Lanka economy. Economic growth in 2009 was 3.5 per cent compared to 6 per cent in 2008, which showed the adverse impact of the financial crisis on the Sri Lankan economy.

Partly due to the adverse effects of the crisis there was a lower growth in government revenue which was significantly below the target level. The total revenue as a per cent of GDP declined to 14.6 per cent in 2009 compared to 14.9 per cent in 2008. The borrowing requirement increased both due to slow growth of revenue and increased expenditure as a result of undertaking massive projects under infrastructural development and requirements in the North and East. Due to tight liquidity conditions in the international capital markets it led the government to depend heavily on domestic borrowings during the first half of 2009. Lower growth in GDP and increased government borrowings resulted in an increase of debt/GDP ratio to 86.2 per cent in 2009. An effort had to be made to borrow from the international market due to tight situation.

The financial system of the country was not directly affected by the crisis. No banks collapsed in Sri Lanka due to contagion effects of the crisis. The regulated openness of the banking sector and the prudential bank supervision in Sri Lanka contributed to these favourable results. Although some registered finance companies faced difficulties in 2008 , there was no threat from a financial crisis to financial stability in the country. However, it was required to maintain 
the public confidence about financial institutions and to avoid panics. The CBSL had to intervene in order to create public confidence which was deteriorating due to adverse developments in the financial institutions around the world. Central Bank attended to this requirement through wide public awareness programmes and press conferences etc. There were no adverse effects on price stability due to the crisis. The average inflation in 2009 was 3.4 per cent, the lowest since 1985. Amidst the financial crises in other countries, Sri Lanka was able to relax its tight monetary policy stance that was maintained prior to third quarter of 2008. Coordinated and timely adoption of monetary policy of the CBSL and the fiscal policies of the government helped in preserving financial system stability of the country despite the crisis took place in the West.

\subsection{Measures that Contributed to Minimise the Adverse Impacts of the US Financial/Economic Crisis on Sri Lanka.}

Similar to the monetary authorities in other countries which were affected by the recent crisis in the US, the CBSL too initiated and pursued a series of precautionary and prudential measures to minimise the impact of the crisis on the domestic financial system. As shown in the previous section, the impact of the financial crisis on the Sri Lankan economy was not severe compared to the adverse impacts experienced by the western countries. However, a prudent management of foreign reserves by the country was required while maintaining a reasonable stability in the exchange rates for other reasons. In order to improve the foreign reserve position and to move away from possible adverse effects on the external sector, the country was required to implement appropriate policies and measures for export growth. In addition to looking after the external sector, the country was also required to maintain financial system stability. Carrying out prudential bank supervision and adopting appropriate regulations were required to protect the financial institutions in the country.

The country was required to change its policies, while at the same time maintaining existing policies and regulatory measures to maintain the stability in the financial system. The following are some of the measures which helped to maintain the system stability in Sri Lanka during and after the difficult time.

\subsubsection{Exchange Control Measures}

- The impact of external shocks had not impacted in an extensive way in the Sri Lankan economy partly due to the country's capital account not being 
fully liberalised. The restrictions on movements of foreign capital flows in Sri Lanka such as permitting the deposits in foreign currencies under specific schemes, requirement of prior approvals for debt capital and other capital transactions and permitting investments in shares through share investment external rupee account, and requirement to maintain foreign currency deposits subject to certain limits helped to minimise adverse impacts of the recent finance crisis. Foreign investments in government securities are subjected to a total cap of 10 percent of outstanding government securities. Although, the CBSL opened the Treasury bill and Treasury bond market to foreigners, these limits were helpful to avoid any threat to external finance from a sudden capital flight. Requirement of foreigners to open a separate account in a licensed commercial bank in Sri Lanka and the permitted limit at 10 percent of the total value of outstanding Treasury bills and Treasury bonds were helpful in preserving Sri Lanka's reserve position.

- The regulatory mechanisms implemented in the country for releasing of foreign exchange only for importers who have licenses issued by Controller of Imports and Exports was also another contributory factor to manage foreign currency situation. There are limits in respect of capital transfers, which have been changed from time to time. Capital account has been prevented from being falling into vulnerabilities through these control measures. These policy measures have been helpful in preventing sudden capital outflows from Sri Lanka.

- The CBSL has implemented some measures, such as allowing limited entry into forward contracts for sale and purchase of foreign exchange, preventing pre-payment on import bills and raising margin deposit requirements against Letters of Credit for importing motor vehicles under the Central Bank's vigilance to maintain a stable exchange rate. These policies were helpful to relieve the pressure on external reserves which may impact due to volatility in the domestic foreign exchange market.

- Further, as a measure to reduce the pressure on the real sector, the CBSL, considering several adverse impacts on domestic economy, favoured a limited depreciation of the Sri Lankan rupee against foreign currencies. As a result, the export sector was not affected too much during the crisis period. The imposition of 100 per cent cash requirement on Letters of Credit opened for the imports of some specific items was also helpful to reduce the outflow of foreign exchange during the crisis period. 
- The maintenance of CBSL's reserves with highly rated international commercial banks ensured 100 percent security and safety of country's reserves. The earnings of foreign currency investments in the international marketenabled the CBSL to supply a part of the foreign exchange requirements to meet the demand for external funds. Also, the CBSL revised its operating instructions issued to authorized dealers in respect of foreign currency sales and purchases enabling the banks to prevent any kind of misuse of foreign currencies. Therefore, the foreign currency dealers are bound to do their business under strict guidelines issued by the Central Bank, which helped to maintain safety in external positions.

- the CBSL intervened in the foreign exchange market in such a way that it stabilised the exchange rate during the crisis period. During the first four months of 2009 increased foreign exchange outflow exerted the pressure on the exchange rate to depreciate and the CBSL supplied foreign exchange. Increased inflows since May 2009 exerted pressure to appreciate exchange rate and the CBSL intervened to maintain stability by buying foreign exchange from the market.

- Issuance of directions to commercial banks by the CBSL for releasing of foreign currencies for travel and other purposes depending on the purpose was another measure to protect foreign currencies of the country. The requirement of producing documentary evidence was helpful to regulate the movements of foreign exchange transactions.

- In order to create confidence among investors/public, the CBSL created a sinking fund thus avoiding undue pressure from withdrawals in the exchange market.

\subsubsection{Bank Supervision Measures}

- Banks operating locally did not have direct exposures to US mortgage securities or to financial instruments that failed. This, as well as existed regulatory framework, safeguarded the domestic financial system. Under the procedures and policies adopted for supervision, the adaptation of Basel II capital adequacy standards for commercial banks in Sri Lanka, effective from January 2008, provided a framework to foster integrated risk management in banks. All banks were required to maintain their capital adequacy ratios and credit ratios as per the guidelines in Basel II which has contributed to promote higher standards of risk management among the banking institutions thus mitigating risks. 
- The issuance of some directions to financial institutions under the corporate governance ensured the improvements in common standards of their behaviour improved the public confidence and thereby contributed positively towards financial stability despite the adverse experiences faced by western financial institutions. Application of the assessment of fitness \& propriety to officers in executive grades of banks came under the corporate governance directions.

- The strict guidelines for maintenance of non-performing loans (NPL) were also helpful to maintain levels of loans as well as to reduce the risk arising from delivery of credit.

- Improving of the financial structure with systems, such as business continuity planning, commencing of risk based supervision and the first time implemented measures such as Know Your Customer (KYC) policy for banks were the other prudential measures implemented by the CBSL to avoid the impacts of crisis.

- Licensed Commercial Banks were instructed not to effect pre-payment of import bills in order to minimize the pressure on external reserves. The CBSL imposed a 100 per cent margin on specific items to avoid possible un-healthy speculating foreign exchange transactions and to help minimizing the risk of banks.

- As a measure to avoid the impact of crisis on financial institutions, the CBSL also appointed managing agents for some banks and finance companies. The directions on the existing Boards of Directors prevented possible un-healthy situations in operations of financial institutions. It also helped to minimise the risk of banks.

- The CBSL also placed limits on the borrowings of Commercial Banks and introduced credit guarantee schemes for bank loans granted to registered finance companies and specialized leasing companies. This was also helpful to protect banks from falling into vulnerabilities.

- Under the legal arrangements several laws relating to financial institutions were amended and guidelines for banks were issued. Some guidelines imposed limitations on payments to executive staff.

- The liquidity problems of some of the domestic banks (eg., Seylan Bank) and some finance companies arose partly due to drying up of external credit lines for their operations were resolved by measures directing them to issue shares and banks to get listed in the Stock Exchange. Also the CBSL, in 
conjunction with Ministry of Finance, introduced special stimulus packages to assist troubled finance companies.

- These carefully thought and timely implemented measures by the CBSL and the government contributed towards ensuring public confidence to maintain stability. Investor awareness programmes and advertisements by the CBSL were also helpful in creating public confidence thus avoiding panics which are harmful to the stability.

\subsubsection{Other Measures}

Other than the above measures, some other measures adopted by the CBSL as given below were helpful in maintaining the price and the financial system stability without impacting much from the crisis.

- Under its monetary policy, the CBSL took several measures. It relaxed its tight monetary policy to supply liquidity to the market. Under a series of measures, Statutory Reserve Requirements (SRR) and restrictions in accessing the Reverse Repo Facility of the CBSL by Commercial Banks and Primary Dealers were removed. These measures were supported by reducing policy rates of the CBSL which helped managing liquidity situation in the market and enabling the banks to lend at a lower rate.

- In order to increase the level of foreign reserves the CBSL and the government took several steps. (a) negotiating with three countries for SWAParrangements (for US \$ $200 \mathrm{mn}$ ) (b) promoting investments in Treasury bills and bonds among Sri Lankan Diaspora and migrant workers. $(c)$ paying bonus interest of 20 per cent in rupee terms on interest earned on NRFC \& RFC deposits.

- The CBSL and the government negotiated with the IMF for a standby arrangement to improve the external reserve position of the country. The IMF under this arrangement promised 2.6 billion US dollars to be given to Sri Lanka. This measure, in addition to improving the foreign currency situation of the country helped creating, more importantly, the confidence of foreigners for investments and other dealings with Sri Lanka. The supply of IMF funds to Sri Lanka increased the level of foreign reserves, substantially in the country. As at end of March 2011, Sri Lanka had received US\$ 1.7 billion under seven tranches out of 8 tranches for US\$ 2.7 billion in totality.

- Timely implementation of monetary policy adjustments helped in maintaining price stability and low inflation. In 2008 there was a tight monetary policy resulting in a low inflation of 7.6 per cent by end of February 2009 
(effect delayed due to time lag) compared to 28.2 per cent in June 2008. Under its tight monetary policy, the CBSL conducted aggressive open market operations (OMO), imposed restrictions of market participation at $\mathrm{OMO}$ and a penal rate of 19 per cent for extra borrowings, and refrained from subscribing to primary and secondary Treasury bill markets. Deceleration of inflation as a result of prudent monetary policy allowed CBSL to further relax its monetary policy in 2009. Under these policies, penal rate of 19 per cent and the repo/reverse repo rates were brought down gradually. During 2010 an accommodative monetary policy with further moderation of interest rates continued.

- Coupled with prudent monetary policy, external sector policies with regard to external trade and exchange rates were helpful in achieving price and economic stability during 2008-2010.

\section{Recovery of the Sri Lankan Economy}

The measures implemented during the crisis period were helpful for Sri Lanka to recover well in the latter part of 2009 and in 2010. The economic growth of 8 per cent recorded in 2010 was impressive. However, the progress achieved by Sri Lanka was not only due to policies implemented to recover from the financial crisis but also due to persistent favourable socio economic conditions, including the conclusion of the civil war which was fought for a period of three decades. Monetary and fiscal policies implemented during 2008-2010 also helped in achieving a remarkable performance of the economy during 2010.

Figure 5

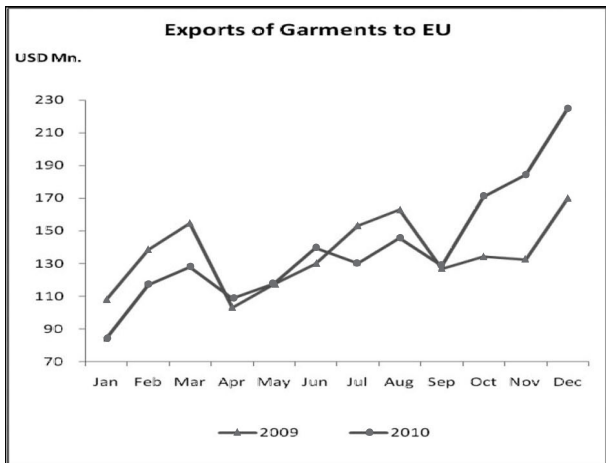

Source : Central Bank of Sri Lanka
Figure 6

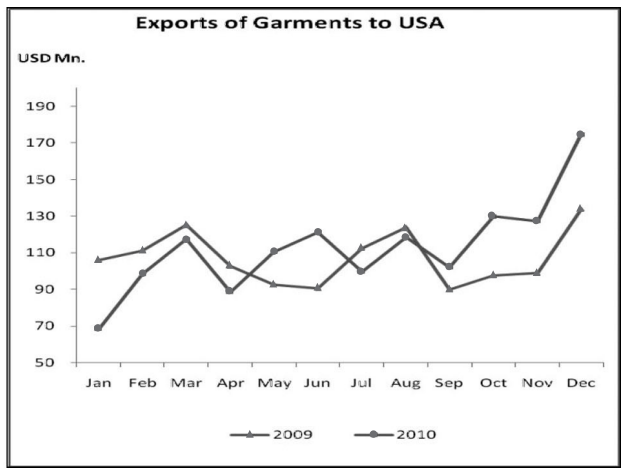

Source : Central Bank of Sri Lanka 
The drop in exports and imports in 2009 reversed in 2010. Exports to major markets increased substantially in 2010. Figure 5 and Figure 6 show rising trends in garment exports to EU countries and to US in 2010 compared to 2009 during which there were some difficulties partly due to slack demand.

Due to external sector policies, coupled with impressive level of foreign remittances especially from the Sri Lankans working abroad and due to government foreign borrowings country's external reserve position improved. External reserves, which dropped to the level of 1.8 months sufficiency for import of goods and services in 2008, rose to a sufficiency of 5.5 months in 2009. The rise in external reserves after policies were implemented is shown in the Figure 7. Total external reserves at end of 2010 amounted to US \$ 6,619 showing 5.9 months of import sufficiency.

Figure 7

External Reserves in Sri Lanka

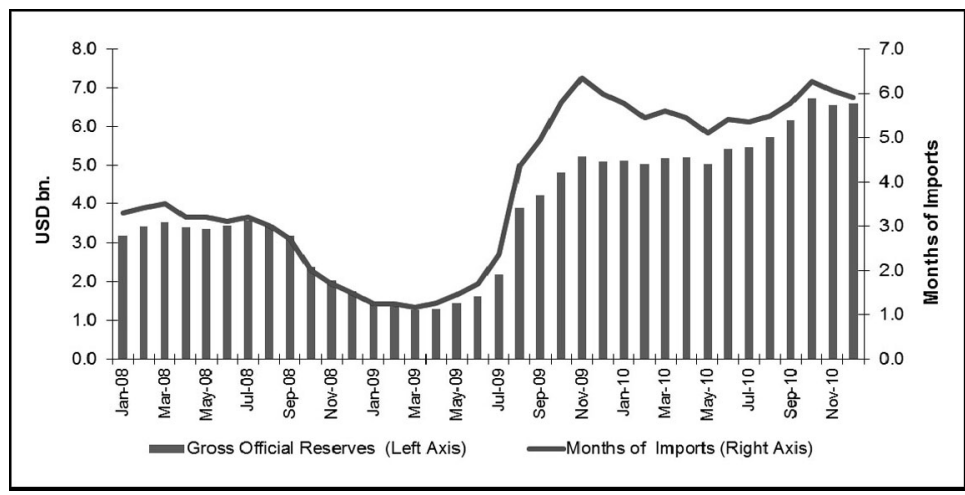

Source : Central Bank of Sri Lanka

The BOP showed a noteworthy improvement starting from the second half of 2009. The country's BOP, which was in a deficit of US \$ 1,225 mn at end of 2008 improved to a surplus of US \$2,725 mn in 2009 and to US \$ $921 \mathrm{mn}$ in 2010 along with supportive macroeconomic policies that were implemented. The inflows of foreign exchange increased due to several reasons including receipt of the Standby Arrangement from the IMF, floating of 2nd international sovereign bond of US \$ $501 \mathrm{mn}$ in October 2009, and foreign investments due to renewed investor confidence and stable exchange rates. Coupled with these, low international interest rates encouraged foreign inflows to government securities, which attracted US \$ 1,369 mn inflows in 2009 as against net outflow of US \$ $213 \mathrm{mn}$ in 
2008. In 2010 third international sovereign bond of US $\$ 1.0$ bn with a tenure of 10 years was floated successfully (Figure 8). Increased remittances from the workers abroad and improvements in tourism contributed to strengthen the BOP situation.

Figure 8

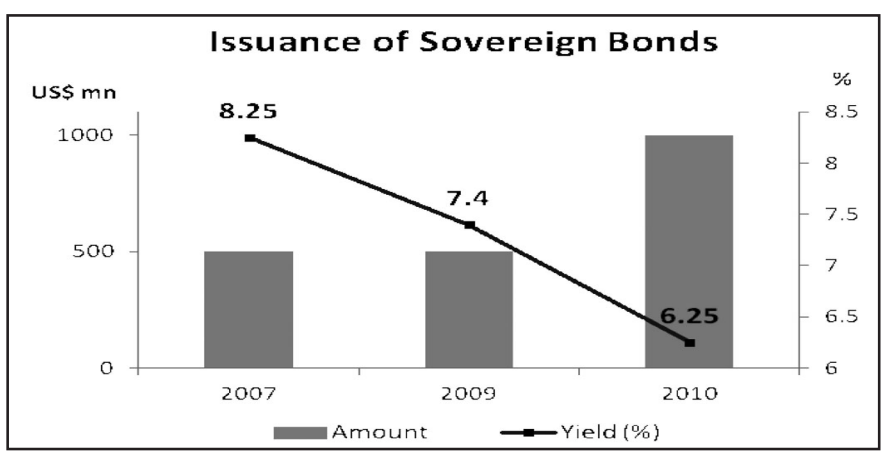

Source : Central Bank of Sri Lanka

Improved socio-economic conditions after concluding the war and favourable developments in political environment in the country were helpful to increase output of factory industry and services sector along with revival of demand from both external and domestic sectors. These conditions resulted in an improved performance of the Colombo Stock Exchange (CSE) in which market capitalisation increased to Rs.2.2 trillion at end of 2010 from Rs. one trillion at end of 2009 showing a rise in the ratio of market capitalisation/ GDP to 42 per cent in 2010 compared to 23 per cent in 2009. Share price indices increased substantially during 2010 (Figure 9) resulting the CSE becoming one of the best performing markets in the world. The All Share Price Index increased by 98 per cent at October 2009 in contrast to a 41 per cent decline recorded in 2008.

The pickup in domestic economic activities and strong recovery in imports increased government revenue which as a percent of GDP increased to 14.6 per cent in 2010. The overall budget deficit declined to 7.9 per cent of GDP in 2010 compared to 9.9 per cent of GDP in 2009. This was helpful in reducing borrowings from domestic banks and therefore in conducting monetary policy. 
Figure 9

Colombo Stock Exchange Price Indices

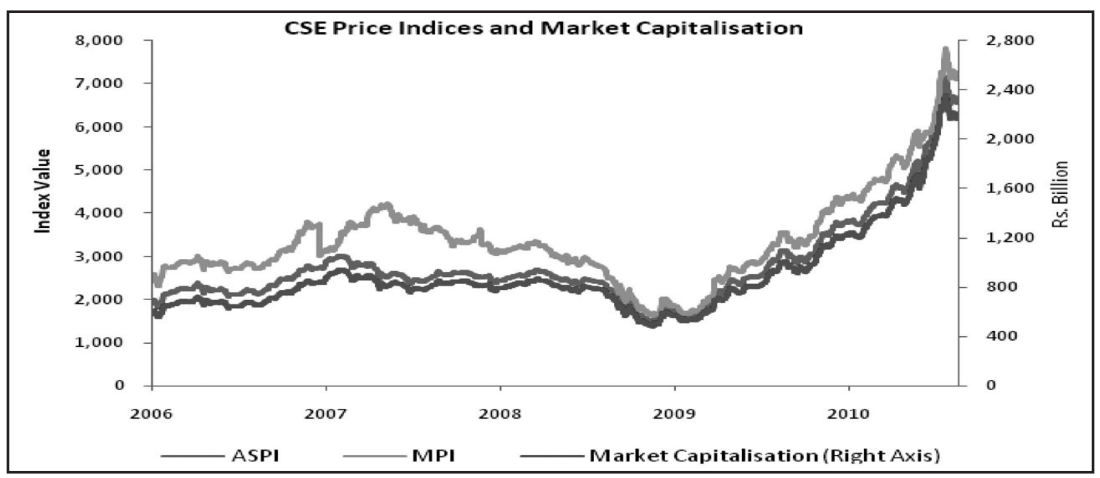

Source : Central Bank of Sri Lanka

The banking sector was resilient to external and domestic developments. No bank in Sri Lanka collapsed due to financial crisis in the world. Financial System stability improved due to implementation of supportive regulatory and supervisory measures. Investor confidence improved and schemes such as mandatory deposit insurance helped improving confidence among the public. Profitability (Figure 10) and capital adequacy of banks (Figure 11) increased. Performances of finance companies in distress also improved in 2010. Credit to private sector from banks grew (Figure 12) and economic activities reactivated. Coupled with these developments supportive regulatory and supervisory framework ensured improved performances in the financial sector and system stability.

Figure 10

Profitability of Banks

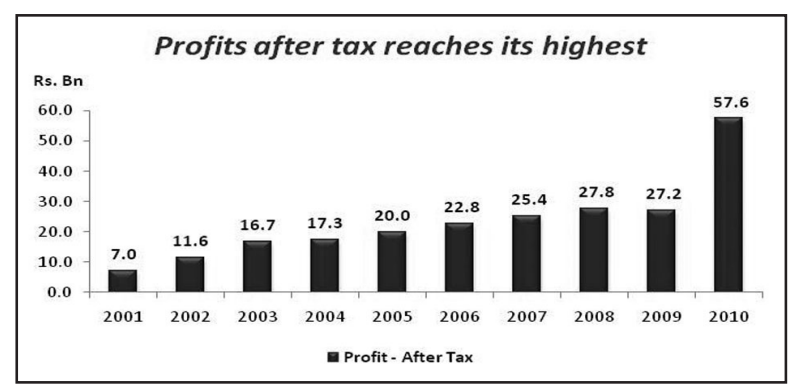

Source : Central Bank of Sri Lanka 
Figure 11

Capital Adequacy of Banks

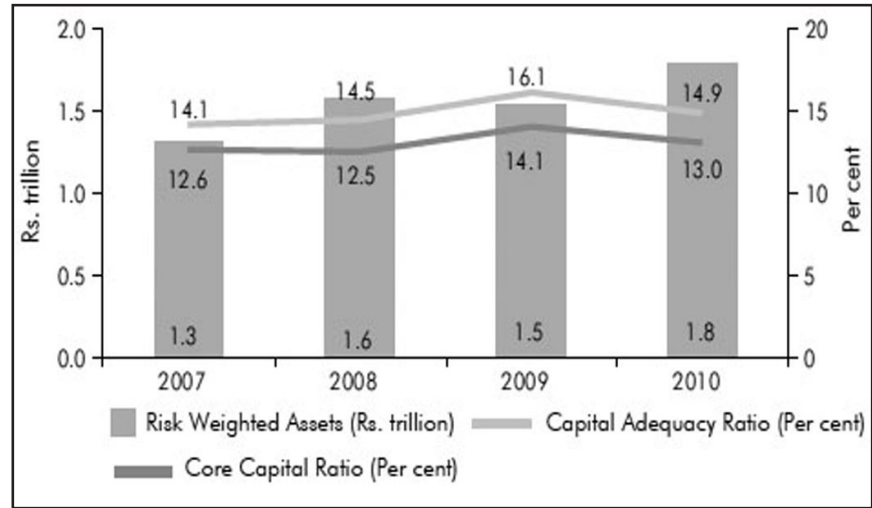

Source : Central Bank of Sri Lanka

Figure 12

Credit to Private Sector by Banks

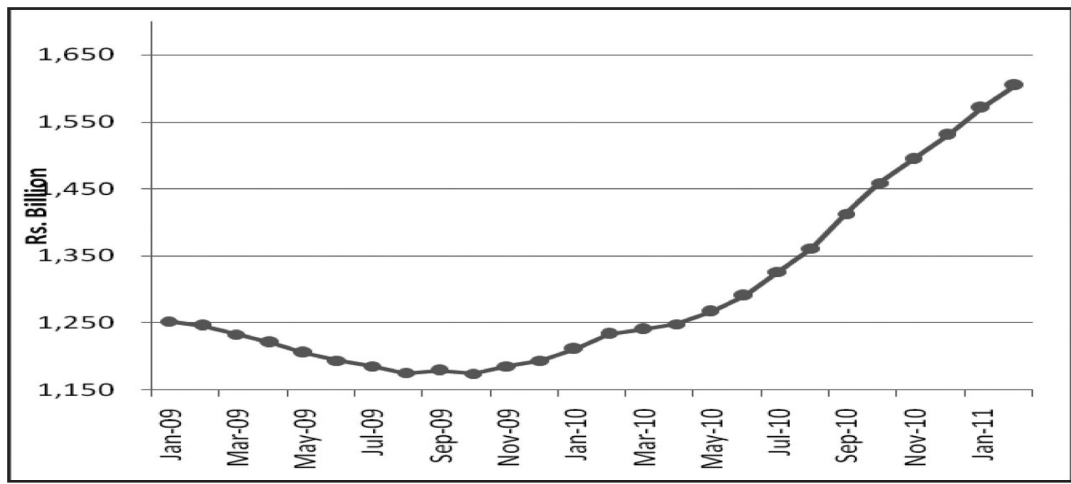

Source : Central Bank of Sri Lanka

Banking services expanded. Expansion in financial institutions (Table 2) at the grass root level provided better services to the public. Bank branch network expanded to grass root level, particularly to the North and East areas, which had suppressed financial performances due to unsettled conditions for many years. Payment and settlement systems with state-of-the art technology ensured confidence and convenience in financial transactions/services. 
Table 2

Improvements in Selected Financial Services

\begin{tabular}{|l|c|c|c|c|}
\hline \multicolumn{1}{|c|}{ Item } & End 2009 & End 2010 & \multicolumn{2}{c|}{ Change in 2010 } \\
\cline { 3 - 5 } & & & Total & $\begin{array}{c}\text { Of which: } \\
\text { North \& East }\end{array}$ \\
\hline Bank Branches & 1,847 & 1,937 & 90 & 29 \\
\hline Other Banking Outlets & 890 & 988 & 98 & 23 \\
\hline ATMs & 1,876 & 2,009 & 133 & 36 \\
\hline Registered Finance Companies & 289 & 376 & 98 & 41 \\
\hline Specialised Leasing Companies & 145 & 224 & 44 & 15 \\
\hline
\end{tabular}

Source : Central Bank of Sri Lanka

Price stability was maintained due to prudent macroeconomic policies. Inflation was under check and maintained at a low level between 4.3 per cent (year-on-year) and 6.9 per cent in 2010 compared to 28.2 per cent in June 2008 (Figure 13). Favourable inflation outlook enabled the CBSL to ease its monetary policy stance further in 2010. The CBSL reduced its policy interest rates several times which resulted in downward adjustments in market interest rates. The money supply growth was under control and remained within the targets. The relaxed monetary policy stance allowed credit to expand (Figure 14) while managing excess liquidity arose from absorption of foreign exchange inflows which increased as a result of issue of sovereign bonds, increase in net foreign investments in government securities and other inflows of foreign exchange for both the government and the private sector.

Figure 13

Achievement of Colombo Consumer Price Index



Source : Central Bank of Sri Lanka 
Figure 14

Money, Credit and Interest Rates

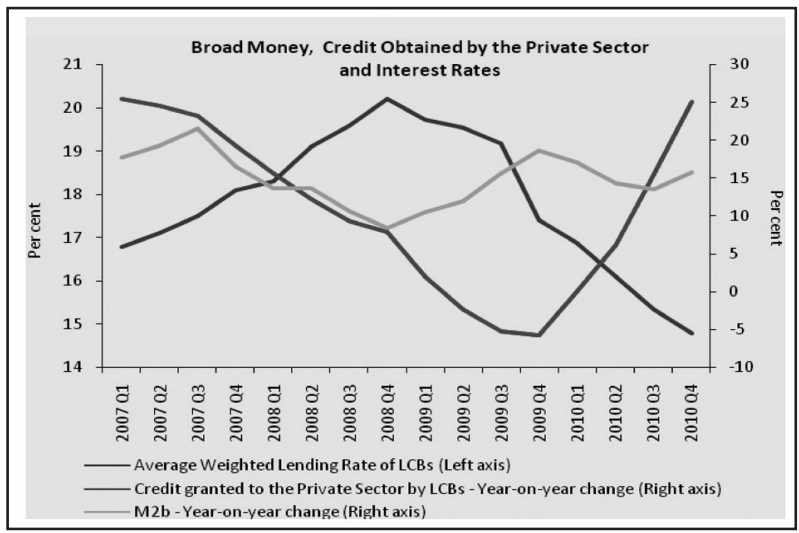

Source : Central Bank of Sri Lanka

As a result of the conducive environment for economic activities, the economy grew at a faster pace. Unemployment rate declined to 4.9 per cent in 2010 which was 8.8 per cent in 2002. Economic growth at 8 per cent in 2010 showed the results of the recovery after the economic crisis of 2008-2009 (Figure 15).

Figure 15

Economic Growth and Unemployment.



Source : Central Bank of Sri Lanka 
As per the above explanation, Sri Lanka has shown that it has recovered from the impacts of financial and economic crises that started in the USA and later on spread globally. The higher economic growth at 8 per cent and the stability in the financial sector have proved that Sri Lanka's macroeconomic settings are on a correct path. However, the country should not be complacent over the 8 per cent economic growth that it has achieved in 2010 as many challenges are ahead due to global and domestic developments. What the country needs is a sustainable growth which requires a considerable effort.

\section{Summary}

This paper attempted to explain the basis for financial crises and their consequences for the countries which suffered from such crises while identifying the measures that the countries have adopted to handle the financial crises, with a particular attention to Sri Lanka.

In the introduction, the paper identified theoretical perspectives of financial crises. Secondly, it identified the causes of the financial crises based on the experiences of financial crises evolved in the recent history of several countries. Some crises occurred due to a combination of several factors. External sector problems such as balance of payments, exchange rates and capital flights were the roots for some crises while excessive debt and credit crunch were some other reasons. From the technological side creation of sophisticated derivative products has contributed to some financial crises. Developments in political front have also been causes for several financial crises. The US crisis and Asian crisis created crises in other countries due to contagion effects. In this study, financial crises evolved in Argentina, Chile, Mexico, Several Asian countries and the US were highlighted as examples. It analysed the sub-prime mortgage crisis started in the US in 2007. The study explained the effects of the US crisis and identified responses to it by US and other countries. Responses, as identified by the study, included monetary policy actions, regulations and legislation measures, government bail-outs and combined policy actions initiated by different countries.

The paper identifies some lessons from the financial crises that were helpful in minimising impacts of the financial crises. It concludes that the latest financial crisis (the US sub-prime mortgage crisis) has not impacted much on the Sri Lankan economy and, as a result of the measures implemented and limited openness of the financial institutions to the external parties, the country was able to recover from adverse impacts.

In the section six indicators are provided to confirm that the economy has recovered from the adverse impacts of the latest financial crisis. The indicators provided include external trade performance with trends in exports, imports and external reserves, performances of stock market, resilience of banking sector with trends in profitability, capital, credit 
provided and improvements in services of financial institutions. Favourable developments in monetary sector were analysed in the light of trends in interest rates, credit and inflation. Finally, it confirms that economic recovery is seen from the high economic growth and lower unemployment rate experienced in Sri Lanka during post-crisis period. However, to face all challenges and to achieve a sustainable growth with stability, a continuous implementation of appropriate policies is required while being vigilant on domestic and international developments. In this process, the policy makers cannot be complacent due to the requirement of pursuing on achieving a sustainable growth while resolving renewed global and domestic challenges. 


\section{References}

Bank for International Settlements, (2010), "The international financial crisis and policy challenges in Asia and the Pacific”, BIS paper No. 52, July 2010.

Bordo, Micheal, (1985), "Some Historical Evidence, 1980-1933 on the impact and International Transmission of Financial Crises", Working Paper No. 1606, National Bureau of Economic Research, (Cambridge, Mass.,).

Cabral, Ajith Niward, (2010), "Lessons Learnt from the Global Financial Crisis", Business Today, May 2010, pp. 30-33.

Central Bank of Sri Lanka, Annual Reports (Various Volumes).

Central Bank of Sri Lanka, (2009, 2010), Financial Stability Review.

Central Bank of Sri Lanka, (2009), "Present Global Financial Crisis and its Implications on Sri Lanka". Unpublished policy paper attended by Policy Review and Monitoring Department.

Corea, Gamani, (1998), "Lessons from the Asian Financial Crisis", Christian Worker, December 1998, pp 28-30.

Espinosa, Marco and Steven Russell, (1996), "The Mexican Economic Crisis: Alternative View”, Economic Review (January/February, 1996).

FT weekends, Various issues.

Frank, Barney, (2011), "Greenspan is Wrong: We can Reform Finance", The Financial Times, 3rd April, 2011.

Giles, Chris, and Megan Murphy, (2011), "IMF Calls for Banks to Pay More to Cover Risk”, The Financial Times, 3rd April, 2011.

Heath, Allister, (2011), "The Top Ten Real Causes of the Crisis", http://goo.gl/jfzFh, February 10, 2011.

Hemachandra, W.M, (2005), "Financial Deepening and Its Implications for the Sri Lankan Economy", Central Bank of Sri Lanka.

Hunter, William C,(ed), Kaufman, George G., (ed), and Krueger, Thomas H. (ed), (1999), "The Asian Financial Crisis: Origins, Implications and Solutions", Boston, Kluwer Academic Publishers, ix, p. 526.

International Labour Organisation, (1998), The Social Impact of the Asian Financial Crisis, Bangkok: ILO Regional Office.

International Monetary Fund, (2011), World Economic Outlook, April 2011. 
Karunatilake, H.N.S., (1986), The Banking and Financial System of Sri Lanka, Centre for Demographic and Socio-Economic Studies, Colombo.

Kindleberger Charles P. and Robert Aliber, (2005), A History of Financial Crises, 5th ed, Wiley.

Krugman,, Paul, (2000), (Ed), Currency Crises, University of Chicago Press, Vol. 0-226-45462-2.

Luc Laeven and Fabian Valencia, (2008), Systemic Banking Crises: a new database, International Monetary Fund Working Paper 08/224.

Latter, Tony, (1997), “Causes and Management of Financial Crises”, Handbooks in Central Banking No. 12, Centre for Banking Studies, Bank of England.

Mauricio, Larrain, (1989), "How the 1981-83 Chilean Banking Crisis was Handled", Background Paper for 1989 World Development Report: The World Bank.

Mayer, Chris and Pence Karen, (2008), "sub-prime Mortgages: What, Where, and to Whom”, Finance and Economic Discussion Series Divisions of Research \& Statistics and Monetary Affairs, Federal Reserve Board, Washington, D.C.

Montes f Manuel, (1998), "Global Lessons of the Economic Crisis in Asia Pacific”.

Moreno, Ramon, Pasadilla, Gloria and Remolona, Eli, (1998), Asia's Financial Crisis: Lessons and Policy Responses, San Francisco: Centre for Pacific Basin Monetary and Economic Studies, July 1998.

Pasadilla, Gloria O., (2001), Soundness of Financial Institutions and Economic Growth: Lessons from the Asian Financial Crisis, Kuala Lumpur, The SEACEN Research and Training Centre.

Rasiah F., Rajakumar, (2008), "Causes and consequences of the Sub-Prime Crisis", the 20th Anniversary Convention of Association of Professional Bankers - Sri Lanka, pp. 195-203.

Recommendations of the Stiglitz Commission on Finance, (2009), Retrieved from http://www.un.org/ga/president/63/commission/financialcommission.shtml.

The Economist, (2011), "Postmortems on the financial crisis, the official verdict", 5th February 2011, p.83.

Tomas J.T., Balino, (1987), “The Argentina Banking Crisis of 1980”, Working paper No. 87/77, International Monetary Fund.

Zhuang, Juzhong, (2003), "Lessons of the Asian Financial Crisis: What can early Warning System Model Tell Us?”, Asian Development Review, 200320 (1). 